Original article

\title{
Seagrasses as potential source of fodder for livestock: Complete proximate and gas chromatography-mass spectrometry (GC- MS) analysis
}

\author{
T.A. Vijayalingam• and N.V. Rajesh \\ Veterinary University Training and Research Centre, Ramanathapuram, Tamilnadu Veterinary and Animal Sciences \\ University, Chennai-600051, Tamil Nadu, India
}

Received October 6, 2019: Revised December 1, 2019: Accepted December 5, 2019: Published online December 30, 2019

\begin{abstract}
The present study analysed the nutritional values of Cymodocea serrulata (R.Br.) Asch. \& Magnus, Syringodium isoetifolium (Asch.) Dandy and Enhalus acoroides (L.f.) Royle by complete proximate analysis and determined the phytocompounds present in them by using Gas Chromatography-Mass Spectrometry (GC-MS) technique. The complete proximate analysis revealed a higher content of crude protein, crude fibre, calcium, phosphorus and energy in all the three grasses under study. However E. acoroides contained higher content of ether extract, lower level of acid insoluble ash and gross energy compared to the other two grasses. The GC-MS analysis showed the presence of decane, sucrose, tetradecanoic acid, deoxyspergualin, n-hexadecanoic acid, phytol, ricinoleic acid, docosyl isobutyl ether and squalene in C. serrulata and decane, sucrose, phytol, 9,12,15-octadecatrienoic acid, (Z,Z,Z)-Triethylene glycol monododecyl ether and Hexadecanoic acid and 2-hydroxy-1-(hydroxymethyl) ethyl ester in S. isoetifolium. Ethanol extract of $E$. acoroides revealed the existence of decane, epoxomicin, tetradecanoic acid, n-hexadecanoic acid, phytol, linoelaidic acid, 9,12,15-octadecatrienoic acid, (Z,Z,Z)-diethylene glycol monododecyl ether, hexadecanoic acid, 1-(hydroxymethyl)-1,2-ethanediyl ester and 15,17,19,21-hexatriacontatetrayne in GC-MS study. All the three seagrasses under study were found to be the rich sources of crude protein, energy, minerals and phytocompounds of varied pharmacological properties which can enable them to be an eligible source of alternative nutritional supplements for ruminants in the areas adjacent to coastal region of Ramanathapuram district, where fodder scarcity exists.
\end{abstract}

Key words: Cymodocea serrulata (R.Br.) Asch. \& Magnus, Syringodium isoetifolium (Asch.) Dandy, Enhalus acoroides (L.f.) Royle, complete proximate analysis, gas chromatography-mass spectrometry, phytocompounds

\section{Introduction}

Seagrasses are submerged type of flora, found in the marine ecosystem, adapted to grow well in the intertidal and midtidal zones of shallow and sheltered areas of sea waters, backwaters and lagoons. They are monocotyledonous plants not belonging to the true grass family Poaceae, but belong to four plant families, viz., Posidoniaceae, Zosteraceae, Hydrocharitaceae, or Cymodoceaceae which are successfully adapted to the marine ecosystem (Ravikumar et al., 2010). In Tamil Nadu, seagrasses are abundantly found in the Gulf of Mannar Biosphere Reserve (Mannar coast and Palk Bay). The Gulf of Mannar coast (area between Pamban and Tuticorin) had predominant species like Halodule uninervis, Thalassia hemprichii and Cymodocea serrulata. The Palk Bay (area between

\footnotetext{
Author for correspondence: Dr. T.A. Vijayalingam

Veterinary University Training and Research Centre, Ramanathapuram, Tamilnadu Veterinary and Animal Sciences University, Chennai600051, Tamil Nadu, India

E-mail: tavijayalingam@gmail.com

Tel.: +91-9597297729
}

Pamban and Athiramapattinam) had a stretch of seagrass cover with dominant species like Thalassia hemprichii, Syringodium isoetifolium and Cymodocea serrulata (Ravikumar et al., 2005). A total of 13 species including 6 genera of seagrasses present in the Mannar Biosphere Reserve. Enhalus acaroides, Halophila ovalis, Halophila ovata, Halophila beccari, Halophila stipulacea, Thalassia hemprichii, Cymodocea serrulata, Cymodocea rotundata, Halodule uninervis, Syringodium isoetifolium are some of the seagrasses available in this biosphere reserve. Thalassia and Syringodium are dominant in the areas of coral reefs and coral rubbles, whereas others are distributed in muddy and sandy soils (Envis, 2015)

C. serrulata, a seagrass occurs extensively in most of the islands of Gulf of Mannar and forms a significant browsing ground for the endangered mammal, Dugong dugon (ENVIS, 2015). It is commonly known as "kadal karumbu" and can be used as food and medicine by fisherman and is utilised by animals as a type of grazing fodder, when fodder scarcity arises (Bharathi et al., 2016). S. isoetifolium, a sea grass belongs to the the family Cymodoceaceae, apparently seen in the Mannar Biosphere Reserve and contains 
large amount of valuable phytocompounds like saponins, flavonoids and alkaloids and are known for its medicinal uses (Albert et al., 2015). E. acoroides belonging to the monotypic marine genus Enhalus in the family Hydrocharitaceae which contain sterol, lignin content and fatty acid components which can be used as a fodder supplement for animals (Gillan et al., 1984).

Seagrasses are important biomass of marine ecosystem and produce greater amount of organic material, even supply basic source of energy in a complicated food web. In India, seagrasses are widely used as medicine, food, fertilizers and livestock feeds (Newmaster et al., 2011; Athiperumalsami et al., 2008; Pradheeba et al., 2011). The crude extracts of seagrasses from the Gulf of Mannar had strong antibacterial (Ragupathi Raja Kannan et al., 2010a; Arumugam et al., 2010) and antioxidant properties (Ragupathi Raja Kannan et al., 2010b; Ragupathi Raja Kannan et al.,2012b). GC-MS analysis is one of ideal chromatographic techniques to find out the phytoconstituents in seagrasses. The phytocompounds are the most essential non-nutritive components secreted by plants and are also known as secondary metabolites which are not utilized by the plants, but used for protective or disease preventive purposes to the human beings (Das and Gezici, 2018). These secondary metabolites are relatively produced in low quantities in plants and have significant economic and medicinal values (Dang, 2018).

The interesting information from the earlier reporters motivated us to undergo this basic level study while observing the consumption of certain ashore plants by the local ruminants in some coastal areas of Ramanathapuram district, Tamil Nadu, India, which is a drought prone area with poor people depending mostly on livestock rearing for their livelihood. The baseline information generated through this study may pave way for the economical usage of these grasses or the product of these grasses as livestock feed/feed supplements.

\section{Materials and Methods}

\subsection{Materials}

\subsubsection{Collection of plants}

The ashore plants found to be consumed by the local goats were collected from the coastal areas near Seeniyappa Dharka and Devipattinam of Ramnathapuram district during May 2019 (summer season).

\subsection{Methods}

\subsubsection{Identification}

The species identification of the plants was done at ICAR-Central Marine Fisheries Research Institute, Mandapam, Ramanathapuram district by gross and microscopic methods and a voucher specimen for Cymodocea serrulata, Syringodium isoetifolium and Enhalus acoroides were deposited at the centre with identification number VUTRC/RMD/ CS 01, VUTRC/RMD/SI 02 and VUTRC/RMD/EA 03, respectively.

\subsubsection{Preparation of plants for investigation}

The collected samples of three different plants were repeatedly washed for 5-6 times in freshwater to remove the traces of impurities. The leaves were shade dried, mechanically pulverised.

\subsubsection{Preparation of extracts}

About $150 \mathrm{~g}$ of grinded powder was initially soaked into $1: 2$ ratio of ethanol for 3 days with mild shaking. After 3 days, the ethanol was decanted, and the collected extract was stored at room temperature in a dark place, and the ethanol solvent was evaporated.
Finally, solid material was collected and stored at $4{ }^{\circ} \mathrm{C}$ until used (Pushpabharathi et al., 2018).

\subsubsection{Complete proximate analysis}

The complete proximate analysis was carried out as per the method of AOAC (2000) to determine the presence of nutritional fractions in the grinded material of the collected plants.

\subsubsection{GC-MS analysis}

GC-MS analysis was carried out at the Department of Agricultural Microbiology, Tamil Nadu Agricultural University, Coimbatore using GC-MS-5975C (AGILENT) under the following conditions as per Gomathi et al. (2015). DB-5ms Agilent (30.0 m $\times 0.25 \mathrm{~mm} \times 0.25$ $\mu \mathrm{m})$ was used. Using helium as carrier gas (99.9995\% purity) at a constant flow rate of $1.51 \mathrm{ml} / \mathrm{min}$ and an injection volume of $2 \mu \mathrm{l}$ was employed in a split mode. The injector temperature was maintained at $240^{\circ} \mathrm{C}$, and the column temperature was programmed to $70^{\circ} \mathrm{C}$ (isothermal for $2 \mathrm{~min}$ ) with increasing temperature of $10^{\circ} \mathrm{C} /$ min to $300^{\circ} \mathrm{C}$ (isothermal for $9 \mathrm{~min}$ ). $200^{\circ} \mathrm{C}$ for ion source temperature and $240^{\circ} \mathrm{C}$ for interface temperature were maintained. The mass spectra were obtained through ionization energy of $70 \mathrm{eV}$ in the EI mode. Total $30 \mathrm{~min}$ need to run GC-MS. The phytocompounds were identified by comparison of mass spectra with the database of National Institute of Standard and Technology (NIST-11) which has 62,000 patterns. The compound name, retention time and the structure were determined. Each components percentage of area was calculated by comparing its average peak area to the total areas. Prediction of biological activities of each compound was done based on as per Duke (2019).

\section{Results}

The freshly collected fully matured plants were identified as C. serrulata, S. isoetifolium and E. acoroides. The grasses collected from Seeniyappa Dharka were C. serrulata and S. isoetifolium and the grass from Devipattinam area was E. acoroides. The complete proximate analysis revealed a higher content of crude protein, crude fibre, calcium, phosphorus and energy in all the three grasses under study. However, E. acoroides contained higher content of ether extract, lower level of acid insoluble ash and gross energy compared to the other two grasses (Table 1).

The GC-MS analysis of ethanol extract of $C$. serrulata, $S$. isoetifolium and $E$. acoroides revealed the presence of phytocompounds that are biologically active. GC-MS chromatogram of $C$. serrulata showed 39 phytocompounds (Figure 1), S. isoetifolium showed 38 phytocompounds (Figure 2) and E. acoroides showed 36 phytocompounds (Figure 3 ). The retention time, compound name, peak area, nature of compound and biological activity of C. serrulata, $S$. isoetifolium and E. acoroides are tabulated (Table 2 to 4 ) as Figure legends with the biological activity of phytocompounds. The notable phytoconstituents seen in C. serrulata were docosyl isobutyl ether $(10.94 \%)$, sucrose $(9.22 \%)$, ricinoleic acid $(5.50 \%)$, n-hexadecanoic acid $(4.56 \%)$ and squalene (3.79\%). The significant phytoconstituents seen in $S$. isoetifolium were n-hexadecanoic acid (12.90\%), sucrose $(8.06 \%), 9,12,15$-octadecatrienoic acid, (Z,Z,Z)$(3.22 \%)$ and triethylene glycol monododecyl ether $(2.80 \%)$. The phytocompounds seen in E. acoroides were n-hexadecanoic acid (15.40\%), diethylene glycol monododecyl ether (12.85\%), 9,12,15octadecatrienoic acid $(9.15 \%)$ and hexadecanoic acid, 1 (hydroxymethyl)-1,2-ethanediyl ester (3.74\%). 
Table 1: Proximate analysis of C. serrulata, S. isoetifolium and E. acoroides

\begin{tabular}{|c|c|c|c|c|}
\hline S.No & Test & Cymodocea serrulata & Syringodium isoetifolium & Enhalus acoroides \\
\hline 1. & Moisture & $10.35 \%$ & $11.06 \%$ & $13.42 \%$ \\
\hline 2 . & Crude Protein & $9.18 \%$ & $9.08 \%$ & $8.73 \%$ \\
\hline 3 . & Crude Fibre & $17.50 \%$ & $17.46 \%$ & $13.07 \%$ \\
\hline 4. & Ether Extract & $1.67 \%$ & $1.56 \%$ & $2.07 \%$ \\
\hline 5. & Total Ash & $21.74 \%$ & $24.66 \%$ & $24.45 \%$ \\
\hline 6. & Acid Insoluble Ash (Sand \& Silica) & $4.94 \%$ & $4.31 \%$ & $2.02 \%$ \\
\hline 7. & Calcium & $2.00 \%$ & $1.59 \%$ & $1.70 \%$ \\
\hline 8. & Phosphorus & $0.28 \%$ & $0.25 \%$ & $0.19 \%$ \\
\hline 9. & Salt & $9.52 \%$ & $12.60 \%$ & $15.68 \%$ \\
\hline 10. & Gross Energy & $2959 \mathrm{kcal} / \mathrm{kg}$ & $2808 \mathrm{kcal} / \mathrm{kg}$ & $2742 \mathrm{kcal} / \mathrm{kg}$ \\
\hline
\end{tabular}

Table 2: Phytocompounds identified in the ethanol extract of C. serrulata using GC-MS analysis

\begin{tabular}{|c|c|c|c|c|}
\hline $\begin{array}{l}\text { Retention } \\
\text { time }\end{array}$ & Compound name & $\begin{array}{l}\text { Peak area } \\
\%\end{array}$ & Nature of compound & Biological activity* \\
\hline 3.26 & Decane & 0.80 & Alkane & Antibacterial activity \\
\hline 9.50 & Sucrose & 9.22 & Disaccharides & Preservative \\
\hline 15.28 & Tetradecanoic acid & 0.94 & Fatty acid derivative & $\begin{array}{l}\text { Antioxidant, cancer preventive, nematicide, } \\
\text { hypercholesterolemic, and lubricant }\end{array}$ \\
\hline 17.93 & Deoxyspergualin & 1.03 & Polyphenols & $\begin{array}{l}\text { Anti-angiogenic action, cytoprotection, } \\
\text { Immunomodulation }\end{array}$ \\
\hline 19.30 & n-Hexadecanoic acid & 4.56 & $\begin{array}{l}\text { Saturated fatty acid } \\
\text { derivative }\end{array}$ & $\begin{array}{l}\text { Antioxidant, hypocholesterolemic, nematicide, pesticide, } \\
\text { antiandrogenic, hemolytic, and alpha reductase inhibitor }\end{array}$ \\
\hline 22.01 & Phytol & 0.96 & Diterpene alcohol & Antimicrobial, anti-inflammatory, anticancer and diuretic \\
\hline 25.71 & Ricinoleic acid & 5.50 & $\begin{array}{l}\text { Unsaturated fatty acid } \\
\text { derivative }\end{array}$ & Antibacterial and antifungal \\
\hline 27.25 & Docosyl isobutyl ether & 10.94 & Ether derivatives & Disinfectant, lubricants \\
\hline 29.20 & Squalene & 3.79 & Triterpene & $\begin{array}{l}\text { Antibacterial, antioxidant, antitumor, cancer preventive, } \\
\text { immune stimulant, chemo preventive, lipoxygenase } \\
\text { inhibitor, pesticide }\end{array}$ \\
\hline
\end{tabular}

*Duke. Phytochemical and ethnobotanical databases

Table 3: Phytocompounds identified in the ethanol extract of $S$. isoetifolium using GC-MS analysis

\begin{tabular}{|c|c|c|c|c|}
\hline $\begin{array}{l}\text { Retention } \\
\text { time }\end{array}$ & Compound name & $\begin{array}{l}\text { Peak area } \\
\%\end{array}$ & Nature of compound & Biological activity* \\
\hline 3.27 & Decane & 2.13 & Alkane & Antibacterial activity \\
\hline 9.57 & Sucrose & 8.06 & Disaccharide & Preservative \\
\hline 19.34 & n-Hexadecanoic acid & 12.90 & Fatty acid derivative & $\begin{array}{l}\text { Antioxidant, hypocholesterolemic, nematicide, } \\
\text { antiandrogenic hemolytic and alpha reductase inhibitor }\end{array}$ \\
\hline 22.03 & Phytol & 1.56 & Diterpene alcohol & Antimicrobial, anti-inflammatory, anticancer and diuretic \\
\hline 22.42 & Linoelaidic acid & 1.24 & $\begin{array}{l}\text { Isomer of linoleic acid } \\
\text { and diabetes }\end{array}$ & Anti-cancer, atherosclerosis, obesity, immuno-modulator \\
\hline 22.52 & $\begin{array}{l}\text { 9,12,15-Octadecatrienoic } \\
\text { acid, }(Z, Z, Z)-\end{array}$ & 3.22 & Fatty acid derivative & $\begin{array}{l}\text { Hypocholesterolemic, nematicide, antiarthritic, } \\
\text { hepatoprotective, antiandrogenic, 5-Alpha reductase } \\
\text { inhibitor, antihistaminic, anticoronary, insectifuge, } \\
\text { antieczemic, antiacne }\end{array}$ \\
\hline 25.08 & $\begin{array}{l}\text { Triethylene glycol } \\
\text { monododecyl ether }\end{array}$ & 2.80 & Ether derivatives & Disinfectant, lubricant \\
\hline 28.66 & $\begin{array}{l}\text { Hexadecanoic acid, } \\
\text { 2-hydroxy-1-(hydroxyl } \\
\text { methyl) ethyl ester }\end{array}$ & 0.90 & Fatty acid derivative & Hemolytic, pesticide, flavouring agent, antioxidant \\
\hline
\end{tabular}

*Duke. Phytochemical and ethnobotanical databases 
Table 4: Phytocompounds identified in the ethanol extract of E. acoroides using GC-MS analysis

\begin{tabular}{|c|c|c|c|c|}
\hline $\begin{array}{l}\text { Retention } \\
\text { time }\end{array}$ & Compound name & $\begin{array}{l}\text { Peak area } \\
\%\end{array}$ & Nature of compound & Biological activity* \\
\hline 3.27 & Decane & 1.53 & Alkane & Antibacterial activity \\
\hline 5.75 & Epoxomicin & 1.48 & Proteasome inhibitor & Anti-inflammatory, parkinson disease \\
\hline 15.38 & Tetradecanoic acid & 1.47 & Fatty acid derivative & $\begin{array}{l}\text { Antioxidant, cancer preventive, nematicide and } \\
\text { hypercholesterolemic }\end{array}$ \\
\hline 19.33 & n-Hexadecanoic acid & 15.40 & Fatty acid derivative & $\begin{array}{l}\text { Antioxidant, hypocholesterolemic, nematicide, } \\
\text { antiandrogenic, hemolytic and alpha reductase inhibitor }\end{array}$ \\
\hline 22.01 & Phytol & 1.49 & Diterpene alcohol & Antimicrobial, anti-inflammatory, anticancer and diuretic \\
\hline 22.42 & Linoelaidic acid & 1.96 & $\begin{array}{l}\text { Isomer of linoleic acid } \\
\text { and diabetes }\end{array}$ & Anti-cancer, atherosclerosis, obesity, immuno-modulator \\
\hline 22.51 & $\begin{array}{l}9,12,15 \text {-Octadecatrienoic } \\
\text { acid }\end{array}$ & 9.15 & Fatty acid derivative & $\begin{array}{l}\text { Hypocholesterolemic, nematicide, antiarthritic, } \\
\text { hepatoprotective, antiandrogenic, 5-Alpha reductase } \\
\text { inhibitor, antihistaminic, antiacne anticoronary and } \\
\text { Antieczemic }\end{array}$ \\
\hline 27.27 & $\begin{array}{l}\text { Diethylene glycol } \\
\text { monododecyl ether }\end{array}$ & 12.85 & Ether derivatives & Disinfectant, lubricant \\
\hline 28.65 & $\begin{array}{l}\text { Hexadecanoic acid, } \\
1 \text {-(hydroxymethyl)-1,2 } \\
\text {-ethanediyl ester }\end{array}$ & 3.74 & Fatty acid derivatives & Lubricants, emollients \\
\hline 28.78 & $\begin{array}{l}15,17,19,21- \\
\text { Hexatriacontatetrayne }\end{array}$ & 0.74 & Acyclic alkanes & Antioxidants \\
\hline
\end{tabular}

*Duke. Phytochemical and ethnobotanical databases

\section{Discussion}

The present study revealed the presence of higher level of crude protein, highest $(9.18 \%)$ in $C$. serrulata and lowest $(8.73 \%)$ in E. acoroides, crude fibre, highest $(17.50 \%)$ in C. serrulata and lowest (13.07\%) in E. acoroides, total ash, $21.74 \%$ in C. serrulata, $24.66 \%$ in $S$. isoetifolium and $24.45 \%$ in E. acoroides and calcium $2.00 \%$ in C. serrulata, $1.59 \%$ in $S$. isoetifolium and $1.70 \%$ in $E$. acoroides. Ragupathi Raja Kannan et al. (2013) reported the nutritional composition like ash, protein, carbohydrate, lipids, fibre, ash, etc. in six sea grasses including $E$. acoroides, $S$. isoetifolium and C. serrulata and stated that protein content ranged from 5.61 to $14.40 \%$ with maximum in $C$. rotundata and least in E. acoroides. Similarly, the crude fibre content was higher in C. serrulata and least in E. acoroides, was in agreement with the study of Ragupathi Raja Kannan et al. (2013). Kanwar et al. (1997) pointed out that the WHO has recommended an intake of 22-23 g of fibre every 1000 $\mathrm{kcal}$ of diet. This quantum of fibre is very much available in these 3 seagrasses, studied especially in C. serrulata and S. isoetifoilum with highest sucrose content ascertained by GC-MS analysis during this study. The sucrose might be reason for the sweeter taste and palatability of the grass, especially during summer seasons (Drew, 1983). The optimum amount of quality fibre available could be well utilised by the ruminants for their better digestibility without constipation.

The GC-MS analysis showed the presence of fatty acid compounds like Tetradecanoic acid, Ricinoleic acid, n-hexadecanoic acid, terpenoids like phytol and squalene, ether derivatives like docosyl isobutyl ether, phenolic derivatives like deoxyspergualin, alkane group like decane and disaccharides like sucrose in $C$. serrulata and decane, sucrose, phytol, hexadecanoic acid, 9,12,15-octadecatrienoic acid (Z,Z,Z)-(fatty acid derivative), Triethylene glycol monododecyl ether and 2-hydroxy-1-(hydroxymethyl) ethyl ester in $S$. isoetifolium. Ethanol extract of $E$. acoroides revealed the existence of decane, epoxomicin (peptide), tetradecanoic acid, 9,12,15octadecatrienoic acid, (Z,Z,Z)-n-hexadecanoic acid, linoelaidic acid, diethylene glycol monododecyl ether, hexadecanoic acid, 1(hydroxymethyl)-1,2-ethanediyl ester, phytol and 15,17,19,21hexatriacontatetrayne (alkane) in GC-MS study. Ravikumar et al., (1993) had reported that $C$. serrulata contained rich bioactive compounds like alkaloids, carboxylic acid, coumarins, flavonoids, phenols, saponins, xanthoprotein, protein, steroids, tannins and sugar. Mani et al., (2012) reported that $S$. isoetifolium contained rich amount of phytoconstituents like resin, glycosides, reducing sugars, saponins, acidic compounds, cardiac glycosides and alkaloids. Vergeer et al., (1995) stated that sea grasses underwent various stress factors and explicit ether derivatives as bioactive compounds which could be used as a disinfectant, emollient and lubricants in skin. The stress was found to be augmented by various vital factors like competitors, predators and continuous grazing conditions. Besides ether, other bioactive components like phenolic acids, sulfated phenolic acids, flavones, condensed tannins, flavonoids and also lignins were elucidated because of stress condition. The increased ether derivatives and polyphenols in this study could also be an indicator of such stresses caused to the grasses. The fatty acid, alcohol and ether derivatives were the common phytocomponents found in all the 3 seagrasses studied. However, deoxyspergualin a polyphenol derivative and phytol and squalene the terpenoid derivatives are seen only in C. serrulata additional to the phytocompounds studied. This study revealed that $C$. serrulata, $S$. isoetifoelium and E. acoroides had both medicinal and fodder values and hence could be commented as plants of phytopharmaceutical importance. 


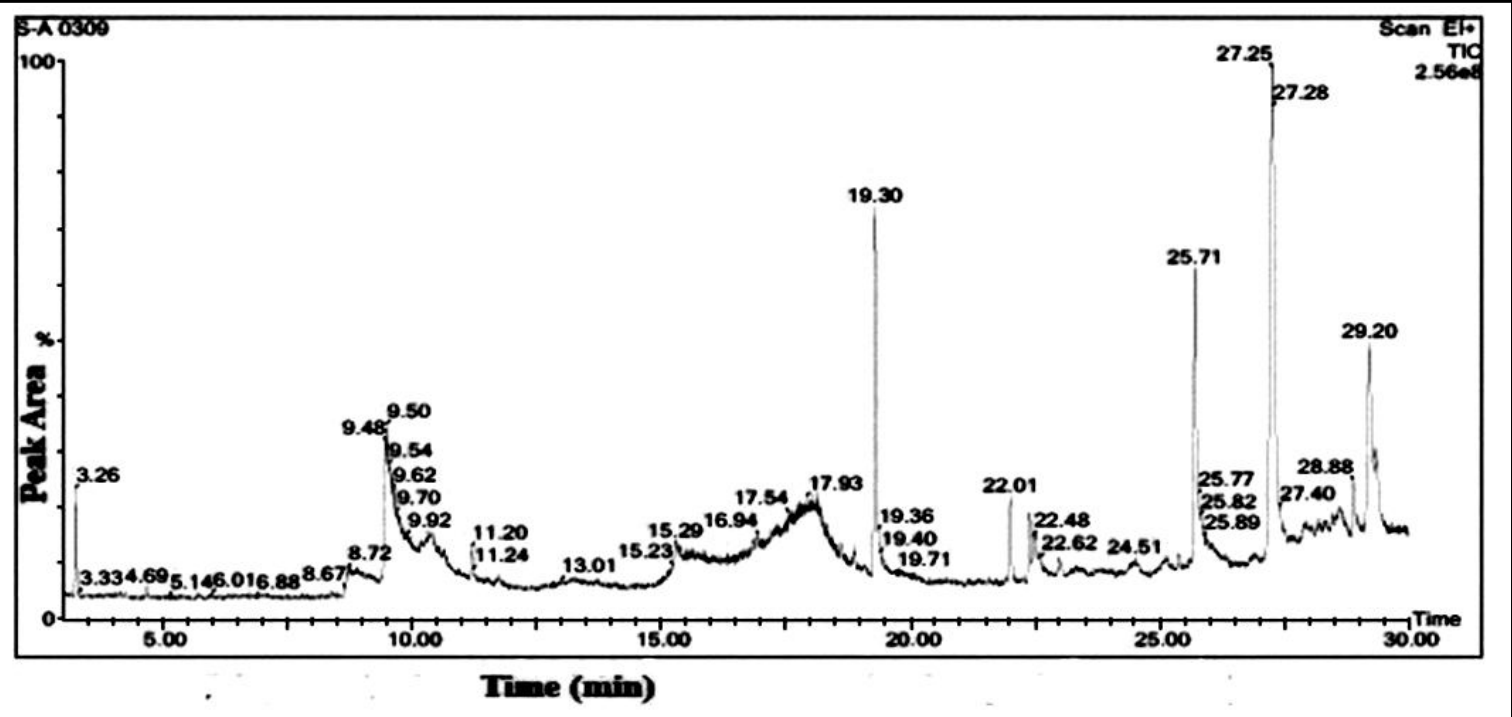

Figure 1: Gas chromatography-mass spectrometry chromatogram of ethanol extract of C. serrulata.

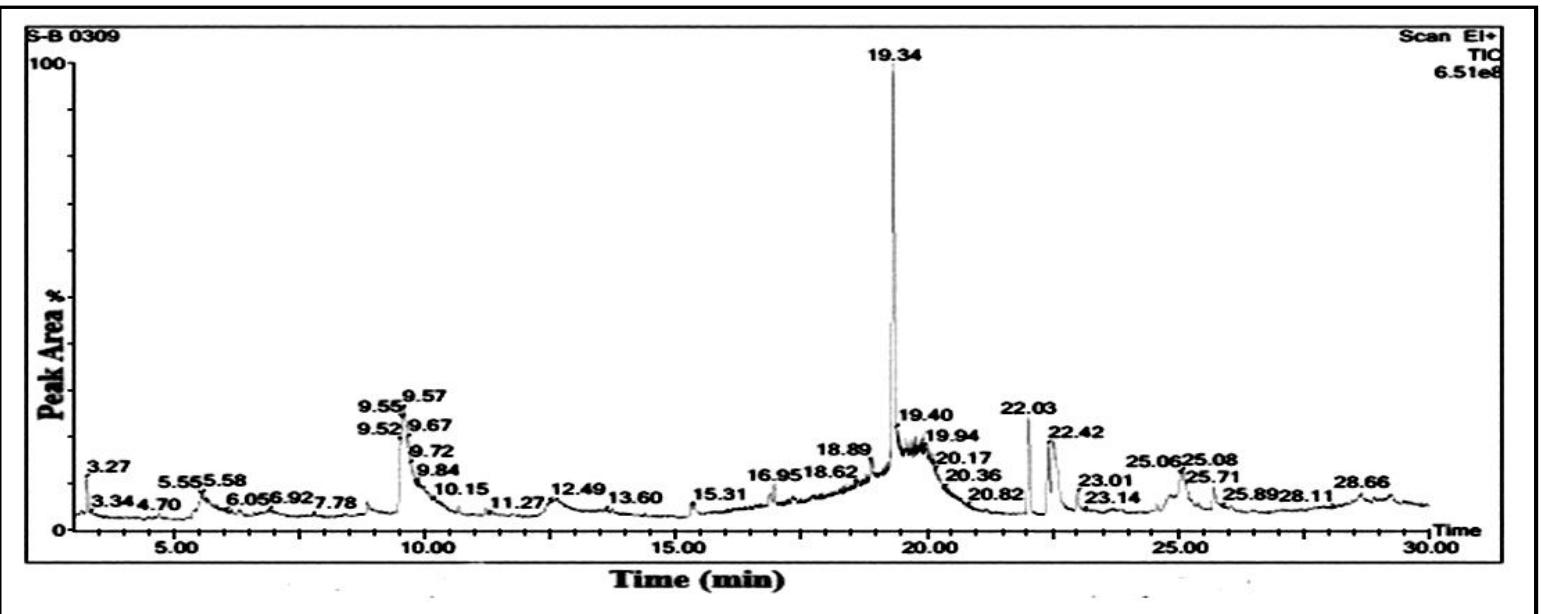

Figure 2: Gas chromatography-mass spectrometry chromatogram of ethanol extract of S. isoetifolium.

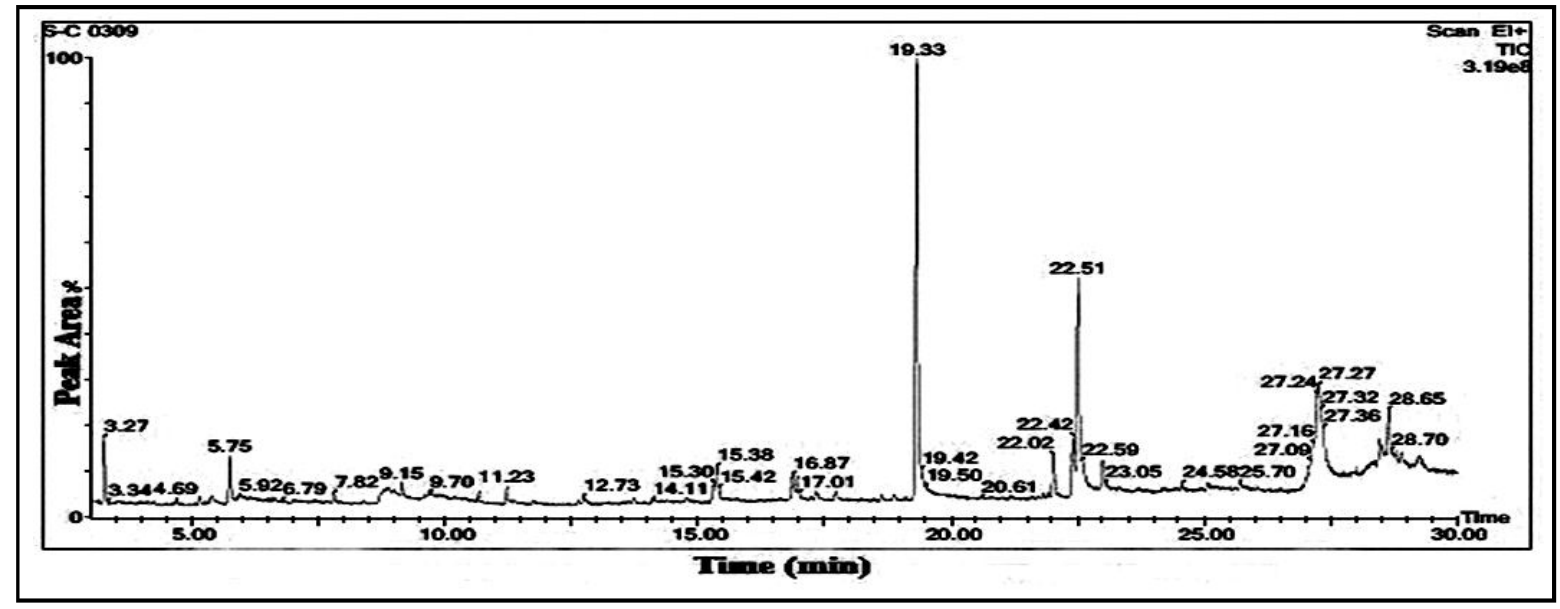

Figure 3: Gas chromatography-mass spectrometry chromatogram of ethanol extract of E. acoroides. 


\section{Conclusion}

These species of seagrasses are unique in nature and are the feeding source for marine mammals such as sea cows and green turtles. However, the suitability of these seagrasses as a fodder alternative/ feed supplement for grazing domestic animals has to be ascertained. In such instances, ways may be thought of to collect these grasses without disturbing the ecological conditions of the sea or to artificially cultivate such grasses in the coastal areas or in certain areas of Ramanathapuram district of Tamil Nadu, India where the ground water is mostly salty in nature. Utmost care should be taken not to disturb the natural biosphere of these areas.

\section{Acknowledgements}

The authors are very much thankful to Tamilnadu Veterinary and Animal Sciences University for providing this wonderful opportunity to bring out this data for the benefits and welfare of scientific community and farmers. The authors are very much happy to extend their heartfelt thanks to Dr. R. Saravanan, Scientist of CMFRI, Mandapam, Ramanathapuram district for the help rendered in the species identification of the grasses. The authors are also very much grateful to Mr. B. Sanjeev, Biocatalyst Laboratory, Department of Agricultural Microbiology, Tamil Nadu Agricultural University, Coimbatore for the help rendered in performing the Gas-Chromatography (GC-MS) analysis.

\section{Conflict of interest}

The authors declare that there are no conflicts of interest in the course of conducting the research. Both the authors had final decision regarding the manuscript and decision to submit the findings for publication.

\section{References}

Albert, J.S.M.; Gayathri, K. and Sorbaraj, R. (2015). Assessment and screening of phyto-chemical components of the seagrasses Cymodocea rotundata and Syringodium isoetifolium and its antibiotic potential. Ijipls., 5(5):1-9.

AOAC (2000). Official methods of analysis of the association of official Analytical Chemists. 17th Ed., Washington, DC.

Arumugam, R.; Ragupathi Raja Kannan, R.; Arivuselvan, N. and Anantharaman, P. (2010). Antimicrobial potential of seagrasses against phytopathogens. Seaweed Res. Util., 32(1-2):177-183.

Athiperumalsami, T.; Venkatraman Kumar, V. and Louice Jesudass, L. (2008). Survey and phytochemical analysis of seagrasses in the Gulf of Mannar, southeast coast of India. Bot. Mar., 51:269-277.

Bharathi, N.P.; Amudha, P. and Vanitha, V. (2016). Seagrasses-novel marine nutraceuticals. Int. J. Pharm. Bio. Sci., 7:567-573.

Dang, R. (2018). Role of antinutrient metabolites of plant on production of secondary metabolites and human health. Ann. Phytomed., 7(1):1-4.

Das, K. and Gezici, S. (2018). Plant secondary metabolites, their separation, identification and role in human disease prevention. Ann. Phytomed., 7(2):13-24.

Duke, J. (2019). Phytochemical and Ethnobotanical Databases. https:// phytochem.nal.usda.gov/phytochem/search/list.

Drew, E.A. (1983). Sugars, cytolitols and seagrass phylogeny. Aquat. Bot., 15(4):387-408.
Envis (2015). Information booklet on gulf of mannar biosphere reserve. pp: $1-34$.

Gillan, F.T.; Hogg, R.W. and Drew, E.A. (1984). The sterol and fatty acid compositions of seven tropical seagrasses from North Queensland, Australia. Phytochem., 23:2817-2821.

Gomathi, D.; Kalaiselvi, M.; Ravikumar, G.; Devaki, K. and Uma, C. (2015). GCMS analysis of bioactive compounds from the whole plant ethanolic extract of Evolvulus alsinoides (L.) L. J. Food. Sci. Technol., 52(2):1212-1217.

Kanwar, K.C.; Kanwar, U. And Shah, S. (1997). Friendly fibres. Sci. Rep., 34:9-14.

Mani, A.E.; Aiyamperumal, V.; Patterson, J. and Devadason, S. (2012). Phytochemicals of the seagrass Syringodium isoetifolium and its antibacterial and insecticidal activities. Eur. J. Biol. Sci., 4(3):63-67.

Newmaster, A.F.; Berg, K.J.; Ragupathy, S.; Palanisamy, M.; Sambandan, K. and Newmaster, S.G. (2011). Local knowledge and conservation of seagrasses in the Tamil Nadu State of India. J Ethnobiol. Ethnomed., 7(37): $1-17$.

Pradheeba, M.; Dilipan, E.; Nobi, E.P.; Thangaradjou, T. and Sivakumar, K. (2011). Evaluation of seagrass for their nutritional value. Ind. J. Mar. Sci., 40(1): 105-111.

Pushpabharathi, N.; Jayalakshmi, M.; Amudha, P. and Vanitha, V. (2018). Identification of bioactive compounds in Cymodocea serrulataA seagrass by Gas Chromatography-Mass Spectrometry. Asian. J. Pharm. Clin. Res., 11(9):317-320.

Ragupathi Raja Kannan, R.; Arumugam, R. and Anantharaman, P. (2010a). Antibacterial potential of three seagrasses against human pathogens. Asian Pac. J. Trop. Med., 11:890-893.

Ragupathi Raja Kannan, R.; Arumugam, R. and Anantharaman, P. (2010b). In vitro antioxidant activities of Enhalus acoroides. Asian Pac. J. Trop. Med., 11:898-901.

Ragupathi Raja Kannan, R.; Arumugam, R. and Anantharaman, P. (2012a). Chemical com-position and antibacterial activity of Indian seagrasses against urinary tract pathogens. Food Chem., 135:2470-2473.

Ragupathi Raja Kannan, R.; Arumugam, R.; Grignon Dubois, M. and Anantharaman, P. (2012b). Antioxidant activity of seagrasses of the Mandapam coast, India. Pharmaceutical Biol., 50(2):182-187.

Ragupathi Raja Kannan, R.; Arumugam, R. and Anantharaman, P. (2013). Seagrasses as potential source of medicinal food ingredients: Nutritional analysis and multivariate approach. Biomed. and Prev. Nutr., 3:375-380.

Ravikumar, S. and Kathiresan, K. (1993). Influence of antioxidant tannins, amino acids and sugar on fungi of marine activity of Aporosa lindleyana root. J. Halophytes. Mahasagar., 26(1):21-25.

Ravikumar, S.; Nazar, S.; Nural Shiefa, A. and Abideen, S. (2005). Antibacterial activity of traditional therapeutic coastal medicinal plants against some pathogens. J. Environ. Biol., 26:383-386

Ravikumar, S.; Thajuddin, N.; Suganthi, P.; Jacob Inbaneson, S. and Vinodkumar, T. (2010). Bioactive potential of seagrass bacteria against human bacterial pathogens. J. Environ. Biol., 31:387-389.

Vergeer, L.H.; Aarts, T.L. and De Groot, J.D. (1995). The "wasting disease" and the effect of abiotic factors (light intensity, temperature, salinity) and infection with Labyrinthula zosterae on the phenolic content of Zostera marina shoots. Aquat. Bot., 52(1-2):35-44.

Citation: T.A. Vijayalingam and N.V. Rajesh (2019). Seagrasses as potential source of fodder for livestock: Complete proximate and gas chromatography-mass spectrometry (GC-MS) analysis. Ann. Phytomed., 8(2):93-98. 